\title{
The connection of manganese and arsenic in unconfined groundwater and shallow confined groundwater of Jianghan plain, China
}

\author{
X. Yu \& Y. Deng \\ Geological Survey, China University of Geosciences, Wuhan, P.R. China
}

\begin{abstract}
The mean content of arsenic (As) in the unconfined groundwater of Jianghan plain is $91.5 \mu \mathrm{g} \mathrm{L}^{-1}$, and the average content of manganese is $1.19 \mathrm{mg} \mathrm{L}^{-1}$. In the shallow confined groundwater $(15-60 \mathrm{~m})$, the content of arsenic is $40.34 \mu \mathrm{g} \mathrm{L}^{-1}$, the average content of manganese is $0.59 \mathrm{mg} \mathrm{L}^{-1}$. With the concentration of manganese rises, the concentration of As drops. In the monitoring field of Jianghan plain, we find that the concentration of manganese has seasonal change, and this change has a tendency to inhabit the reduction of arsenic. This can be explained that the reduction of manganese consumed the reducer of system.
\end{abstract}

\section{INTRODUCTION}

Naturally arsenic (As) enrichment of groundwater is a subject of great concern, which has been reported from numerous countries worldwide (Bai et al., 2016). In addition to Bangladesh, China is one of the countries with the worst endemic arsenic poisoning. The contents of arsenic and manganese in the Jianghan plain are very high. In particular, manganese oxides have been shown to oxidize aqueous $\mathrm{As}(\mathrm{III})$ and $\mathrm{Fe}(\mathrm{II})$, enhance sorption of the oxidize $\mathrm{As}(\mathrm{V})$, and enhance sequestration of arsenic in the sadiment (Bai et al., 2014)

\section{METHODS/EXPERIMENTAL}

\subsection{Study area}

Jianghan plain is a plain formed by the alluvial deposits of the Yangtze river and the Han River. At the high arsenic groundwater monitoring site in Shahu town, 10 $\mathrm{m}, 25 \mathrm{~m}$ and $50 \mathrm{~m}$ of monitoring wells are monitored through hydrogeological drilling. The 10-meter monitoring (A) well is located in the shallow pore aquifer, $25 \mathrm{~m}$ (B) well in the shallow confined aquifer.

\subsection{Sampling and analysis}

Temperature, $\mathrm{pH}, \mathrm{EC}$, and Eh were measured on site using a portable $\mathrm{pH}, \mathrm{EC}$, and Eh meter in-situ (HACH HQ40D, USA). $\mathrm{NH}_{4}-\mathrm{N}, \mathrm{Fe}^{2+}$ and sulfide were measured on site using a portable spectrophotometer ( $\mathrm{HACH} 2800$ ). Concentrations of $\mathrm{HCO}_{3}^{-}$were measured within $24 \mathrm{~h}$ using acid-base titration methods. Total concentration of dissolved ions $(\mathrm{Ca}, \mathrm{Mg}, \mathrm{Na}$, $\mathrm{K}, \mathrm{Fe}$, and $\mathrm{Mn}$ ) was determined using an inductively coupled plasma atomic emission spectrometer (ICPAES) (IRIS Intrepid II XSP, USA). Anions such as $\mathrm{Cl}^{-}, \mathrm{NO}_{3}^{-}$, and $\mathrm{SO}_{4}^{2-}$ were determined using an ion chromatograph.

\section{RESULTS AND DISCUSSION}

\subsection{Spatial distribution of manganese and its influence on the arsenic content of groundwater}

The mean content of arsenic in the unconfined groundwater of Jianghan plain is $91.5 \mu \mathrm{g} \mathrm{L}^{-1}$, and the average content of manganese is $1.19 \mathrm{mg} \mathrm{L}^{-1}$ (Fig. 1). In the shallow confined groundwater $(15-60 \mathrm{~m})$, the content of arsenic is $40.34 \mu \mathrm{g} \mathrm{L}^{-1}$, the average content of manganese is $0.59 \mathrm{mg} \mathrm{L}^{-1}$ (Fig. 2). The concentration of manganese had two peaks at $5 \mathrm{~m}$ and $15 \mathrm{~m}$. Arsenic reaches its peak at about $20 \mathrm{~m}$. With the concentration of manganese rises, the concentration of arsenic drops. There is a negative correlation between the changes of arsenic and manganese. Seasonal variation of manganese and the relation to arsenic (Deng et al., 2014).

Both the concentration of manganese and arsenic in unconfined groundwater under the shallow un-fined

Table 1. Statistics of groundwater chemical data in Jianghang plain.

\begin{tabular}{|c|c|c|c|c|c|c|c|}
\hline \multirow[b]{2}{*}{ Index } & \multirow{2}{*}{$\begin{array}{l}\text { Depth } \\
\text { Unit }\end{array}$} & \multicolumn{3}{|c|}{$0-15 \mathrm{~m}$} & \multicolumn{3}{|c|}{$15-60 \mathrm{~m}$} \\
\hline & & Max & Min & Mean & Max & Min & Mean \\
\hline $\mathrm{pH}$ & & 5.58 & 8.15 & 7.07 & 6.17 & 8.3 & 6.93 \\
\hline $\mathrm{Eh}$ & $\mathrm{mV}$ & 254.3 & 171.5 & -145.1 & 360.5 & 152.1 & 2.827 \\
\hline $\mathrm{Ca}$ & $\mathrm{mg} \mathrm{L}^{-1}$ & 3.54 & 92.4 & 113.38 & 0.27 & 96.2 & 85.39 \\
\hline $\mathrm{Mg}$ & $\mathrm{mg} \mathrm{L}^{-1}$ & 1.041 & 60.3 & 26.37 & 0.871 & 49.5 & 20.81 \\
\hline $\mathrm{Na}$ & $\mathrm{mg} \mathrm{L}^{-1}$ & 0.598 & 48.8 & 26.65 & 0.355 & 46.1 & 16.36 \\
\hline $\mathrm{HCO}_{3}^{-}$ & $\mathrm{mg} \mathrm{L}^{-1}$ & 50.1 & 918 & 493 & 170.6 & 983 & 548.3 \\
\hline $\mathrm{SO}_{4}^{2-}$ & $\mathrm{mg} \mathrm{L}^{-1}$ & 0 & 99.6 & 45.33 & 0 & 86.7 & 4.63 \\
\hline $\mathrm{Fe}^{4}$ & $\mathrm{mg} \mathrm{L}^{-1}$ & 0 & 9.66 & 2.45 & 0 & 9.97 & 5.7 \\
\hline $\mathrm{Mn}$ & $\mathrm{mg} \mathrm{L}^{-1}$ & 0 & 7.43 & 1.19 & 0 & 5.32 & 0.59 \\
\hline As & $\mu \mathrm{g} \mathrm{L}^{-1}$ & 0 & 91.5 & 15.12 & 0 & 96.2 & 40.34 \\
\hline $\mathrm{S}^{2-}$ & $\mu \mathrm{g} \mathrm{L}^{-1}$ & 0 & 490 & 11.93 & 0 & 224 & 6.68 \\
\hline
\end{tabular}



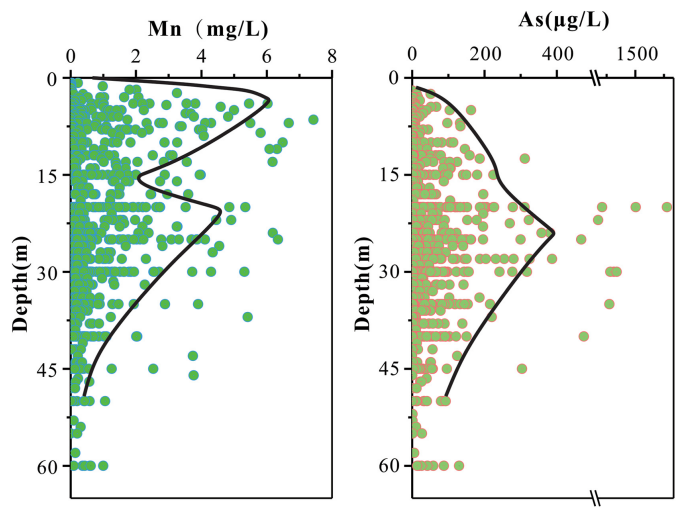

Figure 1. The concentration changes of arsenic and manganese in the unconfined groundwater and shallow confined groundwater of Jianghang plain.
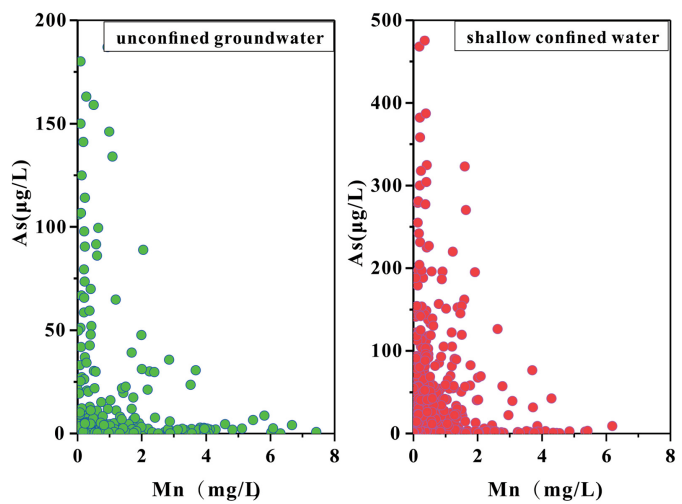

Figure 2. The relationship between arsenic and manganese in groundwater of Jianghang plain.

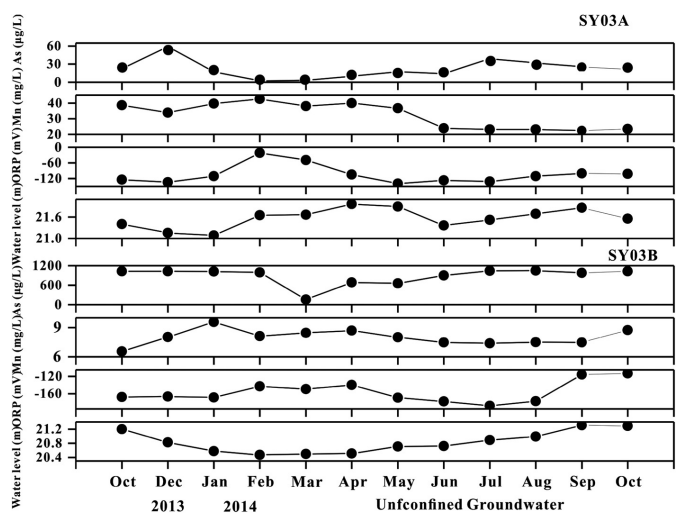

Figure 3. Temporal variation of chemical indices in confined groundwater from October 2013 to October 2014.

groundwater had obvious seasonal changes. The concentration of arsenic increased significantly during the period from June to September, and the concentration of arsenic decreased significantly after the dry period

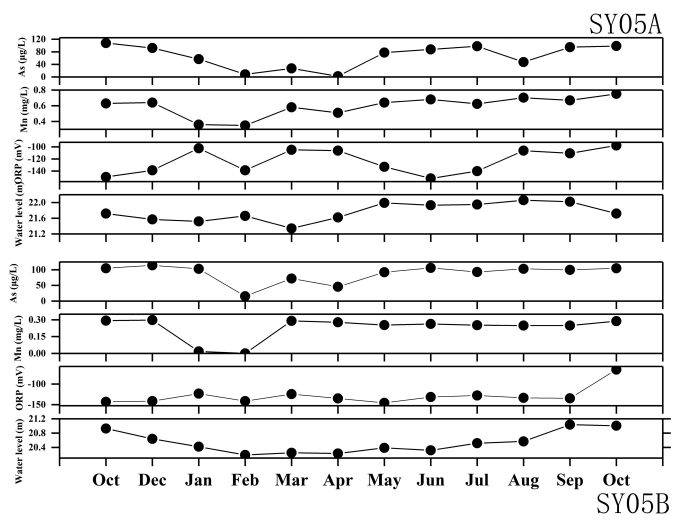

Figure 4. Temporal variation of chemical indexs in shallow cofined groundwater from October 2013 to October 2014.

(Fig. 3). The content of manganese rises sharply from the end of the harvest period and falls sharply around the dry period and starts to recover sharply in March (Fig. 4). When the concentration of arsenic rose, the concentration of manganese rise slowly. These data indicate the concentration of manganese can control the release of arsenic.

\section{CONCLUSIONS}

In the unconfined groundwater and shallow confined groundwater of Jianghang plain, the concentration of manganese has a certain influence on the changes of arsenic. There is a negative correlation between the changes of arsenic and manganese. When the concentration of manganese in the groundwater is increased, the concentration of arsenic decreases. The seasonal variation in the concentration of manganese and arsenic are different, they have the opposite trend in the selling period. It may be that the reduction of manganese consumed the reducer of system and inhibited the release of arsenic.

\section{ACKNOWLEDGEMENTS}

The research was financially supported jointly by National Natural Science Foundation of China (41102153, 41120124003).

\section{REFERENCES}

Bai, Y.H., Yang, T.T., Liang, J.S. \& Qu, J.H. 2016. The role of biogenic Fe-Mn oxides formed in situ for arsenic oxidation and adsorption in aquatic ecosystems. Water Res. 98: 119-127.

Deng, Y.M., Li, H.J., Wang, Y.X., Duan, Y.H. \& Gan, Y.Q. 2014. Temporal variability of groundwater chemistry and relationship with water-table fluctuation in the Jianghan plain, central China. Proc. Earth Planet. Sci. 10:100-103. 